\title{
NA TEMAT DRITTWIRKUNG W NIEMCZECH ODPOWIEDŹ NA POLEMIKĘ BARTOSZA SKWARY ${ }^{1}$
}

\author{
ON DRITTWIRKUNG IN GERMANY. \\ A REPLY TO POLEMIC BY BARTOSZ SKWARA
}

\begin{abstract}
The article is a reply to polemic comments from Bartosz Skwara ("Sejm Review" 2017, no. 1) to my article Horyzontalne działanie praw podstawowych w Niemczech, [w:] Oddziaływanie wspótczesnych konstytucji na stosunki między podmiotami prywatnymi, red. M. Florczak-Wątor, Kraków 2015 [Horizontal effects of fundamental laws in Germany, in: The impact of modern constitutions on legal relationships between private entities, ed. M. Florczak-Wator, Krakow 2015]. As stressed in the article and in accordance with the objective of the book, my interest lay in the analysis of applying the Drittwirkung concept in the constitutional jurisprudence of the FRG; it was not my goal to thoroughly discuss approaches to the issue of horizontality of human rights as presented in the German dogmatic theory. This stems from the fact that courts tribunals ultimately set the standard for the protection of rights of an individual, both in vertical and horizontal relations. The article presents arguments disproving the thesis proposed by the author of the polemic that in the FRG there dominates the direct version of Drittwirkung. It is unfound both as regards the German jurisprudence and the doctrine of law.
\end{abstract}

Słowa kluczowe: Drittwirkung, RFN, wymiar horyzontalny praw podstawowych, orzecznictwo konstytucyjne, Federalny Sąd Konstytucyjny RFN, polemika

Key words: Drittwirkung, FRG, horizontal dimension of fundamental rights, constitutional jurisprudence, Federal Constitutional Court of the FRG, polemic

* Dr Iwona Wróblewska, Uniwersytet Mikołaja Kopernika w Toruniu, Wydział Prawa i administracji, Katedra Prawa Konstytucyjnego, iwona_wroblewska@wp.pl

7 agadnienia związane z koncepcją tzw. horyzontalnej skuteczności praw i wolności konstytucyjnych stały się przedmiotem szerszej debaty naukowej w polskiej doktrynie prawa dopiero w ostatnim dziesięcioleciu. W efekcie dotychczasowych badań rośnie liczba publikacji podejmujących różne aspekty tej problematki zarówno ukazujących rozwój i funkcjonowanie koncepcji w innych systemach prawnych, jak i ujmujących ją z perspektywy praw i wolności uregulowanych w Konstytucji RP. Fundamentalne znaczenie tej problematyki dla konstytucjonalizmu najpełniej wyraża się w leżącym u jej źródeł przeświadczeniu, że współczesne ustawy zasadnicze nie moga być jedynie instrumentami regulującymi organizację aparatu państwowego, ale powinny pełnić rolę normatywnego katalogu dla całego społeczeństwa ${ }^{2}$.

${ }^{1}$ Artykuł powstał w ramach projektu badawczego pt. „Drittwirkung der Grundrechte jako konstrukcja prawna. Doświadczenia niemieckie i rekomendacje dla Polski” finansowanego przez Narodowe Centrum Nauki (2014/15/B/HS5/03190).

${ }^{2}$ U. Preuss, The German Drittwirkung Doctirne and Its Socio-Political Background, [w:] The Constitution in Private Relation: Expanding Constitutionalism, red. A. Sajo, R. Uitz, Utrecht 2005, s. 23. 
Dlatego za cenne należy uznać wypowiedzi przedstawicieli doktryny prawa poświęcone temu problemowi, w tym zwłaszcza takie, które są próbą nawiązania dyskusji z ustaleniami innych autorów. Wydaje się, że cel taki przyświecał Bartoszowi Skwarze, który punktem wyjścia do przedstawienia swoich przemyśleń na temat horyzontalnego obowiązywania praw człowieka uczynił poszczególne rozdziały książki pod redakcją Moniki Florczak-Wątor, Oddziaływanie współczesnych konstytucji na stosunki między podmiotami prywatnymi. B. Skwara, zgodnie z tytułem swojego artykułu „W obronie bezpośredniego horyzontalnego obowiązywania praw człowieka”, który ukazał się na łamach „Przeglądu Sejmowego”, krytycznie odnosi się do prezentowanej w tej książce tezy o dominacji koncepcji pośredniego horyzontalnego obowiązywania praw człowieka w przedstawionych w niej systemach prawnych, za adekwatną uznając koncepcję przeciwną. Jedną z części składowych artykułu B. Skwary (s. 82-85) jest polemika z rozdziałem mojego autorstwa, poświęconym Drittwirkung w Niemczech ${ }^{4}$. W niniejszych uwagach chciałabym odpowiedzieć na zarzuty zawarte w polemice, jednocześnie nawiązując do niektórych wątków poruszonych przez autora we wstępie. Uważam bowiem, że teza przewodnia polemiki nie znajduje potwierdzenia ani w orzecznictwie, ani w doktrynie prawa RFN, a szereg argumentów mających wspierać zarzuty pod adresem poszczególnych fragmentów mojego wywodu budzi wątpliwości różnej natury, w tym merytorycznej.

We wstępie swojego artykułu B. Skwara kwestionuje zasadność podziału horyzontalnego obowiązywania praw człowieka na bezpośrednie i pośrednie (s. 80-81). Czyni to przez pryzmat koncepcji absolutnego obowiązywania praw człowieka autorstwa H.C. Nipperdeya, którego nazwisko zresztą wielokrotnie pojawia się w omawianym tekście we fragmentach poświęconych innym państwom przywołanym w zbiorze, będąc niejako motywem przewodnim całości rozważań. Autor polemiki forsuje w sposób bezwględny tezę, że powyższy podział jest deprecjacją myśli tego prawnika, mówiącego o Drittwirkung bezprzymiotnikowym, czyli absolutnym, mieszczącym w sobie zarówno bezpośrednie, jak i pośrednie obowiązywanie horyzontalne. B. Skwara kontestuje tym samym prawidłowość ustaleń funkcjonujących w niemieckiej nauce prawa, w której — w kontekście nazwiska H.C. Nipperdeya - horyzontalne obowiązywanie absolutne utożsamia się z bezpośrednim, a jego uważa za prekursora tej koncepcji ${ }^{5}$. Rzeczywiście, w pierwszym okresie obowiązywania niemieckiej Ustawy Zasadniczej w piśmiennictwie naukowym — nie tylko zresztą w pracach H.C. Nipperdeya — termin Drittwirkung sprowadzano do bezpośredniego horyzontalnego oddziaływa-

3 „Przegląd Sejmowy” 2017, nr 1, s. 79-101.

${ }^{4}$ I. Wróblewska, Horyzontalne działanie praw podstawowych w Niemczech, [w:] Oddziaływanie wspótczesnych konstytucji na stosunki między podmiotami prywatnymi, red. M. Florczak-Wątor, Kraków 2015, s. 17-41.

${ }_{5}^{5}$ Vide np. Ch. Starck, Die Grundrechte des Grundgesetzes — zugleich ein Beitrag zu den Grenzen der Verfassungsauslegung, „Juristische Schulung” 1981, s. 243; I. von Münch, [w:] I. von Münch, Ph. Kunig, Grundgesetz-Kommentar, t. 1, München 2000, s. 39; M. Ruffert, Vorrang der Verfassung und Eigenständigkeit des Privatrechts. Eine verfassungsrechtliche Untersuchung zur Privatrechtswirkung des Grundgesetzes, Tübingen 2001, s. 12; R. Alexy, Teoria praw podstawowych, Warszawa 2010, s. 397. 
nia praw podstawowych ${ }^{6}$, aby — wobec licznych zarzutów kierowanych pod adresem tej teorii ${ }^{7}$ - sformułować przede wszystkim opartą na praktyce orzeczniczej ograniczona jej wersję. Dostrzegam w tym procesie nie deprecjację doktryny, lecz jej rozwój nakierowany na zapewnienie efektywnej ochrony prawom podstawowym przy utrzymaniu rozumienia konstytucji jako aktu zabezpieczającego jednostkę przede wszystkim przeciwko działaniom państwa.

Komentarza wymaga treść przywołanej przez B. Skwarę ,powszechnie przyjętej w doktrynie prawa konstytucyjnego" definicji bezpośredniego Drittwirkung jako „orzekania w sprawach cywilnych na podstawie normy konstytucyjnej z pominięciem normy prawa cywilnego" (s. 81). Należy wyjaśnić, że pojęcie bezpośredniego, czyli absolutnego Drittwirkung odnoszone jest w niemieckiej nauce prawa do możliwości uznania podmiotów prywatnych za adresatów praw podstawowych, tzn. powoływania się przez jednostki na te prawa bezpośrednio zarówno w relacjach wertykalnych, jak i horyzontalnych, ale — w ślad za nauką H.C. Nipperdeya — dotyczy to tylko niektórych praw podstawowych, a mianowicie tych, które jednocześnie „,pełnią funkcję norm zasadniczych bezpośrednio obwiązujących w całym systemie prawnym, a więc również w prawie prywatnym"». Bezpośrednia skuteczność nie ma więc charakteru generalnej zasady, ale wymaga potwierdzenia w przypadku poszczególnych praw podstawowych pod kątem ich treści, istoty i funkcji ${ }^{9}$. Co więcej, jak wskazała M. Florczak-Wątor, większość przedstawicieli doktryny niemieckiej przychyliła się do poglądu H.C. Nipperdeya i W. Leisnera, że orzekanie na podstawie konstytucji ma w relacjach horyzontalnych charakter subsydiarny, a więc aktualizuje się dopiero wtedy, gdy normy prawa prywatnego nie zapewniają wystarczającej ochrony prawom podstawowym ${ }^{10}$.

W świetle powyższych ustaleń naturalny wydaje się wniosek, że odmian horyzontalnego działania praw jednostki nie należy sobie stanowczo przeciwstawiać. Kwestię rozróżnienia między pośrednim i bezpośrednim Drittwirkung uważam w istocie za niezwykle interesujący, zasługujący na osobne opracowanie wątek dyskusji o działaniu horyzontalnym. Obie teorie zbliża do siebie już choćby okoliczność, że według wskazanej wcześniej opinii zwolenników bezpośredniego Drittwirkung, nie obowiązuje ono jako bezwględna zasada, ale wymaga każdorazowego potwierdzenia w odniesieniu do konkretnych praw. Słuszne jest w tym kontekście twierdzenie B. Skwary, że podział, o którym mowa, podstawowe znaczenie ma przede wszystkim w obszarze uzasadniania wyroków sądowych (s. 81). Nie ukrywa tego również Federalny Trybunał Konsty-

${ }^{6}$ Widoczne jest to np. w pracy H. Lindersa, Über die Frage der unmittelbaren Bedeutung der Grundrechtsbestimmungen des Bonner Grundgesetzes für den privatrechtlichen Rechtsverkehr. Ein Beitrag zum Problem der „Drittwirkung“ der Grundrechtsbestimmungen, Bielefeld 1961, maszynopis, s. 27-41.

7 Treść tych zarzutów została już przedstawiona w polskiej literaturze. Vide przede wszystkim M. Florczak-Wątor, Horyzontalny wymiar praw konstytucyjnych, Kraków 2014, s. 83-86; I. Wróblewska, Poziome dziatanie praw jednostki jako rozwiqzanie ustrojowe, ,Przegląd Prawa Konstytucyjnego” 2014, nr 1, s. $62-64$.

8 Vide H.C. Nipperdey, [w:] K.A. Bettermann, H.C. Nipperdey, U. Scheuner, Die Grundrechte, t. IV/2, Berlin 1962, s. 748 cyt. przez Ch. Starck, op. cit., s. 748.

${ }^{9}$ Ch. Starck, op. cit., s. 243; M. Ruffert, op. cit., s. 12.

${ }_{10}$ M. Florczak-Wątor, Konstytucyjny wymiar..., s. 70. 
tucyjny [dalej: FTK], formułując w jednym ze swoich nowszych rozstrzygnięć wniosek, że: „pośrednie obowiązywanie praw podstawowych może być tak samo intensywne, jak ma to miejsce w przypadku obowiązywania bezpośredniego, zwłaszcza jeśli podmiot prywatny wykonuje funkcje tradycyjnie należące do państwa""11. Jeśli jeszcze, jak uczynił to B. Skwara, dokonywać analizy tej problematyki przez pryzmat koncepcji R. Alexy'ego, który podkreślał konieczność komplementarnego ujęcia różnych odmian działania horyzontalnego (nie tylko dwóch tutaj wskazanych), za uzasadnione uważam twierdzenie, że problem podziału Drittwirkung jest — przynajmniej pod pewnymi względami - pozorny.

Świadomość powyższych racji nie może jednak badaczowi interesującej nas tematyki przesłonić faktu, że utrwalonym elementem współczesnej dogmatyki horyzontalnego obowiązywania praw podstawowych w RFN, będącym najczęstszym punktem wyjścia dyskusji na ten temat, jest podział na pośrednie i bezpośrednie Drittwirkung ${ }^{12}$. Co więcej, a co ma kluczowe znaczenie w kontekście twierdzeń B. Skwary, nie da się zakwestionować faktu, że w orzecznictwie FTK obowiązuje wersja pośrednia tej teorii. Uprzedzając dalsze wywody, należy podkreślić, że w przypadku słynnego wyroku z 15 stycznia 1958 r. w sprawie Lüth ${ }^{13}$ również nie może być mowy o realizacji koncepcji bezpośredniego Drittwirkung, ponieważ istotą tego rostrzygnięcia jest zanegowanie bezpośedniego obowiązywania praw jednostki i podkreślenie ich charakteru jako przede wszystkim praw obronnych przeciwko państwu. Artykuł B. Skwary jest jedynym znanym mi opracowaniem, w którym próbuje się forsować wniosek przeciwny. W niemieckim orzecznictwie koncepcję bezpośredniej horyzontalności praw prezentował w okresie powojennym Federalny Sąd Pracy, by zarzucić ją w latach osiemdziesiątych ${ }^{14}$. Jeśli chodzi o Federalny Trybunał Sprawiedliwości, to poza niektórymi rozstrzygnięciami wydanymi przede wszystkim w okresie po wejściu w życie Ustawy Zasadniczej, w których opowiedział się on za bezpośrednim Drittwirkung ${ }^{15}$, następnie nie kontynuował tej linii orzeczniczej ${ }^{16}$.

11 Vide wyrok FTK z 22 lutego 2011 r. w sprawie Fraport, 1 BvR 699/06, BVerfGE 128,226.

12 Vide np. I. von Münch, [w:] I. von Münch, Ph. Kunig, op. cit., s. 39 i n.; M. Ruffert, op. cit., s. 12 i n; H. Jarass, [w:] H. Jarass, B. Pieroth, Grundgesetz für die Bundesrepublik Deutschland. Kommentar, München 2004, s. 56-57; A. Guckelberger, Die Drittwirkung der Grundrechte, „Juristische Schulung” 2003, nr 12, s. 1151 i n., a także publikacje przywołane w tekście, którego dotyczy polemika. Ujęcie wyodrębniające pośrednie i bezpośrednie Drittwirkung jest prezentowane w większości niemieckich podręczników. Obok tych dwóch koncepcji wyodrębnia się jeszcze model obowiązków ochronnych państwa, który ze względu na ścisły związek z koncepcją pośredniego Drittwirkung nie został w moim artykule omówiony. Więcej na ten temat w polskiej literaturze vide: M. Florczak-Wątor, Konstytucyjny wymiar..., s. 126-150; P. Radziewicz, Pojęcie horyzontalnego skutku norm konstytucyjnych - uwagi wprowadzajace z perspektywy prawa konstytucyjnego, [w:] Horyzontalne oddziatywanie Konstytucji Rzeczypospolitej Polskiej oraz Konwencji o Ochronie Praw Człowieka i Podstawowych. Wolności, red. A. Młynarska-Sobaczewska, P. Radziewcz, „Studia i Materiały Trybunału Konstytucyjnego”, t. LVI, Warszawa 2015, s. 37.

13 Wyrok z 15 stycznia 1958 r. w sprawie Lüth, sygn. 1 BvR 400/51, BverfGE 7, 198.

14 I. von Münch, [w:] I. von Münch, Ph. Kunig, op. cit., s. 39; M. Ruffert, op. cit., s. 13.

15 Vide np. wyrok z 25 maja 1954 r. w sprawie Veröffentlichung von Briefen, sygn. I ZR 211/53, BGHZ 13,334 .

${ }^{16}$ I. von Münch, [w:] I. von Münch, Ph. Kunig, op. cit., s. 39. 
Najczęściej przywoływanym normatywnym argumentem na rzecz odrzucenia skuteczności praw konstytucyjnych w relacjach horyzontalnych, jest art. 1 ust. 3 UZ, w którym wśród podmiotów związanych tymi prawami w sposób bezpośredni zostały wymienione: ustawodawstwo, władza wykonawcza $\mathrm{i}$ wymiar sprawiedliwości ${ }^{17}$. Bezpośrednie horyzontalne działanie praw podstawowych akceptuje się jedynie wtedy, gdy przepis Ustawy Zasadniczej wyraźnie taką możliwość przewiduje. Ma to miejsce przede wszystkim w przypadku wskazanych w moim tekście art. 1 ust. 1 zd. 1 , art. 9 ust. 3 zd. 2, a także - co jednak nie jest w świetle analiz doktrynalnych akceptowane bez różnego rodzaju zastrzeżeń — art. 19 ust. 3, art. 20 ust. 4 oraz art. 48 UZ.

Istotnym ogniwem argumentacji B. Skwary, będącym jednocześnie punktem wyjścia uwag polemicznych, wydaje się kwestia dokonanego przeze mnie doboru orzeczeń FTK. Zdaniem B. Skwary, dowodząc, że FTK opowiedział się za pośrednim horyzontalnym działaniem praw podstawowych, pomijam „kilka kluczowych wyroków”. Zarówno to twierdzenie, jak i towarzyszącą mu enumerację orzeczeń uważam za nieporozumienie. Przede wszystkim nie jest jasne, na czym polega „kluczowe” znaczenie wskazanych przez B. Skwarę wyroków. Z całą pewnością nie mogą one być argumentem na rzecz wiodącej $\mathrm{w}$ tekście polemiki tezy o adekwatności teorii bezpośredniego horyzontalnego obowiązywania praw człowieka. W zasadzie wszystkie z nich, poza jednym w sprawie Fraport, w przypadku którego - moim zdaniem — mamy do czynienia z co najwyżej z pozornym Drittwirkung, wpisują się w linię orzeczniczą zapoczątkowaną w 1958 r. w sprawie Lüth. I tak, w wyroku w sprawie Sozialplan ${ }^{18}$ chodzi o wykładnię planu socjalnego przyjętego $\mathrm{w}$ formie porozumienia między przedsiębiorstwem a radą zakładowa, a więc instrumentu zaliczanego przez FTK, podobnie jak układy zbiorowe, do prawa prywatnego, w kontekście tzw. negatywnego prawa koalicji z art. 9 ust. 3 UZ. B. Skwara podkreślił fakt zastosowania przez FTK ,określenia Geltung (obowiązywanie) w kontekście rozszerzenia skutku decyzji prawnopodstawowej na obszar prawa prywatnego", nie wyjaśniając bliżej dlaczego miałoby to przesądzać na rzecz jego interpretacji. FTK używa tego pojęcia w znaczeniu „,wpływania”, „oddziaływania” praw podstawowych na normy prawa prywatnego, które odbywa się za pośrednictwem odpowiedniej interpretacji klauzul generalnych i innych zwrotów otwartych. Taki proces określa się mianem tzw. oddziaływania promieniującego (Ausstrahlungswirkung) lub pośredniego Drittwirkung. Związek $\mathrm{z}$ bezpośrednią wersją omawianej tu teorii polega w przypadku tego rozstrzygnięcia na czymś innym. Jednym z wzorców konstytucyjnych w sprawie Sozialplan, którego naruszenia FTK $w$ tym konkretnym przypadku nie stwierdził, jest bowiem

${ }^{17}$ Confer np. H. Jarass, [w:] H. Jarass, B. Pieroth, Grundgesetz für die Bundesrepublik Deutschland. Kommentar, München 2004, s. 56; Ph. Kunig, [w:] I. von Münch, Ph. Kunig, Grundgesetz - Kommentar..., s. 107-116; M. Ruffert, op. cit., s. 13. M. Florczak-Wątor zwraca uwagę, że zwolennicy bezpośredniego Drittwirkung interpretują ten przepis inaczej, mianowicie w taki sposób, że nie wyklucza on związania prawami podstawowymi podmiotów prywatnych. Vide M. Florczak-Wątor, Konstytucyjny wymiar..., s. 72. Uważam, że co najwyżej można ten przepis uznać za generalną klazulę pośredniej skuteczności praw podstawowych w relacjach prywatnoprawnych.

18 Wyrok z 23 kwietnia 1986 r. w sprawie Sozialplan, sygn. 2 BvR 487/80, BVerfGE 73, 261. 
art. 9 ust. 3 UZ, a więc ten przepis, którego zdanie 2. w powszechnej opinii niemieckich konstytucjonalistów wyraża jasny zamiar twórców Ustawy Zasadniczej nadania mu bezpośrednego skutku horyzontalnego.

Odwołanie do obiektywnego systemu wartości jest wyraźnie zaakcentowane również w wyroku w sprawie Mephisto ${ }^{19}$, który jest wzorcowym przykładem zastosowania w orzecznictwie koncepcji pośredniej horyzontalnej skuteczności ${ }^{20}$. Odnotował to zresztą B. Skwara, który napisał w kontekście tego wyroku, że ukazuje on ,wpływ ducha praw podstawowych na prawo cywilne". Również w przypadku pozostałych orzeczeń $^{21}$, których sygnatury przywołuje autor polemiki, trudno dopatrzeć się uzasadnienia dla tezy o aprobowaniu przez FTK koncepcji przeciwnej.

Błędne jest też, moim zdaniem, przywołanie wyroku z 22 lutego 2011 r. w sprawie Fraport ${ }^{22}$ jako egzemplifikacji zastosowania bezpośredniego Drittwirkung. Wynika ono z niewłaściwego zaklasyfikowania gospodarczo-mieszanego podmiotu, zdominowanego w sensie liczby udziałów przez państwo jako podmiotu prywatnego. Decydujacce znaczenie ma, w opinii FTK, nie forma prawna, w jakiej dany podmiot działa, ale kto jest rzeczywistym uczestnikiem stosunków prawnych. W tym sensie przedsiębiorstwo Fraport, zorganizowane jako spółka akcyjna, jest ,prywatne” jedynie w znaczeniu formalnym, a nie materialnym. Mamy tu więc do czynienia z przypadkiem relacji ${ }^{23}$, która tylko z pozoru ma charakter prywatnoprawny, a zatem nie można w jej przypadku zasadnie mówić o którejś z form horyzontalnego działania praw podstawowych. FTK w uzasadnieniu wyroku wyraźnie rozróżnia między bezpośrednim związaniem prawami podstawowymi, wyrażonym terminem unmittelbare Grundrechtsbindung, a pośrednim Drittwirkung, jedynie dla państwa rezerwując ten pierwszy termin ${ }^{24}$.

W odniesieniu do omówionych przeze mnie wyroków niemieckich sądów B. Skwara stwierdził ponadto, że ,pominięcie” orzecznictwa konstytucyjnego ostatnich 20 lat może ,istotnie zdeformować obraz wewnętrznego zróżnicowania teorii horyzontalnego obowiązywania praw człowieka" odsyłając w tym punkcie — w sposób ogólny, bez komentarza czy wskazania stron — do wydanej w Niemczech w 2004 r. monografii południowokoreańskiego autora, który porównuje problematykę Drittwirkung w RFN i swoim kraju ${ }^{25}$. Odpowiadając na ten zarzut, należy zauważyć, że wy-

${ }_{19}$ Wyrok z 24 lutego 1971 r. w sprawie Mephisto, sygn.1 BvR 435/68, BVerfGE 30, 173.

${ }^{20}$ Vide np. w polskiej literaturze takiej klasyfikacji dokonuje M. Florczak-Wątor, op. cit., s. 109.

${ }_{21}$ Wyrok z 15 grudnia 1999 r. w sprawie Caroline von Monaco II, sygn. 1 BvR 653/96, BVerfGE 101, 361; wyrok z 13 września 2007 r. w sprawie Vaterschaftsfeststellung, sygn. 1 BvR 421/05, BVerfGE $117,202$.

22 Vide wyrok z 22 lutego 2011 r. w sprawie Fraport, sygn. 1 BvR 699/06, BVerfGE 128, 226. B. Skwara błędnie oznacza datę wyroku jako 22 września $2011 \mathrm{r}$.

${ }^{23}$ W sprawie chodziło o spór między osobą prywatną a zarządcą lotniska o to, czy na jego terenie można demonstrować.

${ }^{24}$ Wyrok ten omawiam I. Wróblewska, Glosa do wyroku Federalnego Sqqdu Konstytucyjnego z dnia 22 lutego 2011 r., 1 BvR 699/06, BVerfGE 128,226 - Fraport, „Przegląd Prawa Konstytucyjnego” 2017, nr 5, s. 285-299.

${ }^{25}$ K.H. Park, Die Drittwirkung der Grundrechte des Grundgesetzes im Vergleich zum koreanischen Verfassungsrecht, Halle (Saale) 2004. 
borowi orzeczeń na potrzeby artykułu towarzyszyło przekowanie, że są one istotnymi, dostrzeżonymi w literaturze niemieckiej przykładami roztrzygnięć obrazujących zastosowanie teorii Drittwirkung do przepisów Ustawy Zasadniczej regulujących poszczególne prawa podstawowe. Z oczywistych względów ich liczba jest ograniczona, nie są one też, rzecz jasna, jedyną możliwą egzemplifikacją stosunku FTK do tej problematyki. Autor polemiki - choćby z uwagi na względy, o których była mowa wcześniej - jednak nie wyjaśnił, dlaczego wskazane przez niego wyroki miałyby być bardziej reprezentatywne od tych, które omówiłam w swoim artykule. Oczywiście każde rozstrzygnięcie w jakiś sposób modyfikuje dotychczasową linię orzeczniczą, odnosząc wcześniejsze ustalenia do charakterystycznego tylko dla danej sprawy stanu faktycznego i prawnego. Zapewne jednak nie tę okoliczność miał na myśli autor polemiki. $\mathrm{W}$ ostatnich latach - wbrew poglądowi forsowanemu przez B. Skwarę - w istocie trudno jest wskazać orzeczenia, które rzucałyby nowe światło na utrwalony punkt dogmatyki Drittwirkung, zgodnie z którym do relacji prywatnoprawnych ma zastosowanie jedynie pośrednia wersja tej koncepcji. Jeśli chodzi o przywołaną monografię, to — wobec wspomnianej ogólności odesłania — można się domyślać, że w jej treści mamy odnaleźć owo „pominięte” orzecznictwo, ukazujące „,wewnętrzne zróżnicowanie" interesującej nas teorii. Tymczasem najnowszy wskazany w niej wyrok FTK pochodzi z 2003 r., a w komentarzu do poszczególnych orzeczeń, z których część pokrywa się $\mathrm{z}$ przywołanymi $\mathrm{w}$ moim artykule ${ }^{26}$, podkreśla się, że - co do zasady — powtarzają ustalenia $\mathrm{z}$ wyroku w sprawie Lüth, żadne natomiast nie daje podstaw do twierdzenia, jakoby FTK opowiedział się za tezą o bezpośrednim Drittwirkung.

Autor polemiki - zarówno w uwagach wstępnych odniesionych do monografii jako całości, jak i fragmencie poświęconym RFN — podnosi zarzut nienależytego docenienia znaczenia godności jako punktu wyjścia rozważań o Drittwirkung. W moim artykule wskazałam, że zasada nienaruszalności godności, którą niemiecka Ustawa Zasadnicza wyraża $\mathrm{w}$ art. 1 ust. 1 powinna być interpetowana jako postanowienie wiążące wszystkie podmioty w sposób bezpośredni. Taki pogląd, dominujący zresztą w piśmiennictwie naukowym w tym kraju, nawiązuje do przeświadczenia towarzyszącego twórcom niemieckiej konstytucji, zgodnie z którym obowiązek poszanowania godności jest „stwierdzeniem absolutnym, skierowanym do wszystkich”, a więc zarówno do władzy, jak i podmiotów prywatnych oraz wszystkich instytucji ${ }^{27}$. Sformułowanie zastosowane $\mathrm{w}$ art. 1 ust. $1 \mathrm{UZ}$, uwypuklając prymat godności jednostki względem państwa jako kategorii wobec niego pierwotnej, jest pomyślane jako wyraźny kontrapunkt do ideologii narodowego socjalizmu ${ }^{28}$. Otwiera cały system prawa na wartości prawnonaturalne. Wyrok w sprawie Lüth, ze względu na strony zaangażowane w spór, $\mathrm{z}$ których jedna była reżyserem filmów antyżydowskich $\mathrm{z}$ okresu III Rzeszy, pośrednio dotyka problemu rozliczenia Niemiec z nazizmem, ale nie da się

${ }^{26}$ Wyrok z 7 lutego 1990 r. w sprawie Handelsvertreter, sygn.1 BvR 26/84, BVerfGE 81, 242, oraz z 19 października 1993 r. w sprawie Bürgschaftsverträge, sygn.1 BvR 567, 1044/89, BVerfGE 89, 214.

${ }_{27}$ Ph. Kunig, [...] I. von Münch, Ph. Kunig, op. cit, s. 82; vide też H. Jarass, [w:] H. Jarass, B. Pieroth, op. cit., s. 47 oraz przywołana tam literatura. $\mathrm{t}$

${ }^{28} \mathrm{Ph}$. Kunig, [w:] I. von Münch, Ph. Kunig, op. cit., s. 68-69. 
raczej obronić tezy B. Skwary, jakoby cel ten był motywacją dla przyjętego rozstrzygnięcia. W moim artykule podkreśliłam, że zasada poszanowania godności, ze względu na jej wyjątkowe znaczenie jako aksjologicznego fundamentu całego systemu prawnego, jest w szczególny sposób predestynowana do tego, aby z niej właśnie uczynić uzasadnienie dla twierdzenia o generalnej skuteczności praw podstawowych w relacjach horyzontalnych. Jeśli uwzględnić powyższą zależność, całkowicie zrozumiałe jest akcentowanie znaczenia godności w myśli zwoleników bezpośredniego Drittwirkung, zwłaszcza gdy mówimy o powojennym okresie renesansu prawa naturalnego, czyli okresie, na który przypada aktywność naukowa H.C. Nipperdeya. Okoliczność, że we współczesnym orzecznictwie sądowym w RFN koncepcja ta nie jest reprezentowana, nie oznacza, że zasada poszanowania godności straciła na znaczeniu. Jako istotny element obiektywnego systemu wartości bezspornie oddziałuje na wykładnię prawa prywatnego w procesie jego stosowania przez sądy, a zatem można powiedzieć, że odbywa się to w drodze pośredniego Drittwirkung. FTK w sprawie Lüth stwierdził, że obiektywny system wartości, który ustanowiono w Ustawie Zasadniczej, wzmacnia moc obowiązywania praw podstawowych.

W komentarzu do stwierdzenia autora polemiki, że w uzasadnieniu wyroku w sprawie Lüth koncepcja G. Düriga — jako skrajna — została odrzucona (s. 85), należy zauważyć co następuje. Publikacja G. Düriga ${ }^{29}$, do której odwołuje się w tym wyroku FTK, zawiera przegląd stanowisk w zakresie znaczenia praw podstawowych w relacjach między podmiotami prywatnymi. Wobec ogólności odesłania, ale przede wszystkim w świetle dalszego wywodu FTK nie może tu chodzić o koncepcję Düriga, ale o poglądy skrajne względem teorii H.C. Nipperdeya, odrzucające możliwość jakiegokolwiek horyzontalnego działania praw podstawowych. W odniesieniu do tej teorii, G. Dürig twierdził, że absolutna wersja działania praw podstawowych w relacjach horyzontalnych jest zrelatywizowana (relativiert ist) do autonomii podmiotów prywatnych. Uważał, że podmioty takie podlegają przepisom konstytucji dotyczącym praw i wolności za pośrednictwem prawa cywilnego. Trudno więc mówić o odrzuceniu przez sędziów FTK teorii G. Düriga w sytuacji, w której centralnym punktem argumentacji Trybunału w wyroku w sprawie Lüth jest odwołanie do „obiektywnego systemu wartości oddziałującego na cały system prawa, w tym na prawo prywatne”. W modelu stworzonym przez G. Düriga przy braku cywilnoprawnych środków ochrony przeciw naruszeniom praw w relacjach horyzontalnych środkiem tym ma być właśnie wypełnianie klauzul generalnych wartościami zakodowanymi w prawach podstawowych. Nie ma natomiast wątpliwości co do tego, że niemiecki sąd konstytucyjny wprost odrzucił koncepcję H.C. Nipperdeya o istnieniu bezpośredniego Drittwirkung, uznając za zbyt daleko idące wcześniejsze twierdzenia Federalnego Sądu Pracy.

W odpowiedzi na zarzut nieuwzględnienia w moim tekście rozważań niemieckich teoretyków prawa, należy zwrócic uwagę na kilka kwestii. We wstępie do całego zbioru znaznaczono, że zaprezentowanie, w jaki sposób współczesne konstytucje oddziału-

${ }^{29}$ Grundrechte und Zivilrechtsprechung, [w:] Von Bonner Grundgesetz zur gesamtdeutschen Verfassung. Festschrift zum 75. Geburtstag von Hans Naviasky, red. T. Maunz, München 1956, s. 157-190. 
ją na stosunki między podmiotami prywatnymi, wymaga przede wszystkim odniesienia się do sposobu ich interpretowania i stosowania w praktyce orzeczniczej. Do sądów i trybunałów należy bowiem ostatnie słowo w zakresie wyznaczenia standardu ochrony praw jednostki zarówno w relacjach wertykalnych, jak i horyzontalnych. Nie było celem artykułu - jako jedynie części pracy zbiorowej - kompleksowe omawianie prezentowanych na przestrzeni lat w niemieckiej ,teorii dogmatycznej” podejść do kwestii horyzontalności. Ich wpływ na ostateczne odczytanie konkretnego przepisu konstytucji w praktyce sądowej, poza zresztą wskazanym przeze mnie przypadkiem H.C. Nipperdeya, wydaje się ograniczony. Dotyczy to również szeroko przywoływanego przez B. Skwarę R. Alexy'ego, którego fundamentalny wkład do niemieckiej refleksji na temat praw podstawowych jest bezsporny. Jeśli natomiast chodzi o zaproponowany przez tego autora trzypłaszczyznowy model Drittwirkung, to jego znaczenie przejawia się głównie w próbie kompleksowego ujęcia już funkcjonujących teorii horyzontalnego działania praw podstawowych: pośrednich, bezpośrednich i horyzontalnie istotnych praw skierowanych przeciwko państwu ${ }^{30}$. W tym sensie ten model nie przedstawia dogmatycznej nowości. Nie znalazł również odzwierciedlenia w orzecznictwie.

Jeśli chodzi o pozostałych wymienionych wraz $\mathrm{z}$ R. Alexym autoró ${ }^{31}$, to odsyłając raz jeszcze do powyższych uwag wyjaśniających centralne założenia i przedmiot zainteresowania mojej publikacji, trzeba zauważyć, że prace te w większości są poświęcone zagadnieniu jedności systemu prawa, które wiąże się z przyjętą przeze mnie perspektywą badawczą jak i samą problematyką horyzontalnego działania praw jednostki jedynie pośrednio. Twierdzenie, że dopiero ich uwzględnienie miałoby zapewnić „obiektywne spojrzenie” na istotę podziału Drittwirkung nie wydaje się uprawnione. Tym bardziej że autor polemiki nie wyjaśnia szerzej tego punktu swojej krytyki, ograniczając się do przywołania nazwisk i tytułów książek. Należy zauważyć, że całokształt rozważań B. Skwary, również we fragmentach dotyczących innych części monografii pod redakcją M. Florczak-Wątor, prowadzony jest z punktu widzenia poglądów dwóch autorów, H.C. Nipperdeya i R. Alexy'ego. Można więc zadać pytanie, czy zastosowanie takiego ujęcia nie oznacza nieuzasadnionego zawężenia problematyki Drittwirkung, co przecież B. Skwara zarzuca mojemu tekstowi.

$\mathrm{Na}$ marginesie powyższych uwag pozostawiam jedynie zasygnalizowaną w polemice kwestię — poprzez odesłanie do publikacji innych autorów — związaną z tłumaczeniem terminu objektive Werteordnung, a także problem kwalifikowania prawa pracy jako prawa publicznego, a nie prywatnego. Wydaje się, że w przypadku prawa pracy, wziąwszy pod uwagę zróżnicowanie relacji podmiotów w ramach indywiduywalnego i zbiorowego prawa pracy, zasadne jest mówienie o jego mieszanym, publiczno-prywatnym charakterze.

W zakończeniu powyższych uwag, chciałabym raz jeszcze podkreślić, że koncepcja horyzontalnego działania praw podstawowych jest obecna w niemieckim piśmiennictwie naukowym od połowy XX w. i już choćby z tego powodu doczekała się po-

${ }^{30}$ R. Alexy, op. cit., s. 484 i n.

31 R. Christensen, A. Fischer-Lescano, F. Echold-Schmidt i J. Habermas. 
kaźnej liczby intepretacji, wariantów i ujęć, w tym także takich, które kwestionują potrzebę wyodrębniania kategorii Drittwirkung ${ }^{32}$. Również jej aplikacja w orzecznictwie konstytucyjnym, która była centralnym punktem zainteresowania mojego artykułu, nie jest przyjmowana w nauce prawa w sposób bezkrytyczny ${ }^{33}$. Należy mieć na uwadze, że badanie konkretnych rozstrzygnięć sądowych pod kątem możliwości przyporządkowania ich do poszczególnych modeli teoretycznych ma tak naprawdę służyć lepszemu zweryfikowaniu praktycznego potencjału koncepcji Drittwirkung w sferze ochrony praw człowieka.

\section{BIBLIOGRAFIA}

ŹRÓDŁA

Federalny Trybunał Konstytucyjny

Wyrok z 15 stycznia 1958 r. w sprawie Lüth, sygn. 1 BvR 400/51, BverfGE 7,198.

Wyrok z 24 lutego 1971 r. w sprawie Mephisto, sygn. 1 BvR 435/68, BVerfGE 30, 173.

Wyrok z 23 kwietnia 1986 r. w sprawie Sozialplan, sygn. 2 BvR 487/80, BVerfGE 73, 261.

Wyrok z 7 lutego 1990 r. w sprawie Handelsvertreter, sygn. 1 BvR 26/84, BVerfGE 81, 242.

Wyrok z 19 października 1993 r. w sprawie Bürgschaftsverträge, sygn. 1 BvR 567, 1044/89, BVerfGE 89, 214.

Wyrok z 15 grudnia 1999 r. w sprawie Caroline von Monaco II, sygn. 1 BvR 653/96, BVerfGE 101,361 .

Wyrok z 13 września 2007 r. w sprawie Vaterschaftsfeststellung, sygn. 1 BvR 421/05, BVerfGE 117, 202.

Wyrok z 22 lutego 2011 r. w sprawie Fraport, sygn. 1 BvR 699/06, BVerfGE 128, 226.

Wyrok Federalnego Trybunału Sprawiedliwości Republiki Federalnej Niemiec z 25 maja 1954 r. w sprawie Veröffentlichung von Briefen, sygn. I ZR 211/53, BGHZ 13, 334.

\section{PIŚMIENNICTWO}

Alexy R., Teoria praw podstawowych, Wydawnictwo Sejmowe, Warszawa 2010.

Dürig G., Grundrechte und Zivilrechtsprechung, [w:] Von Bonner Grundgesetz zur gesamtdeutschen Verfassung. Festschrift zum 75. Geburtstag von Hans Naviasky, red. T. Maunz, Isar Verlag, München 1956.

Eschenbach J., Nienbaum F., Von der mittelbaren Drittwirkung unmittelbar zur staatlichen Bevormundung, „Neue Zeitschrift für Verwaltungsrecht” 1994, nr 11.

Guckelberger A., Die Drittwirkung der Grundrechte, „Juristische Schulung” 2003, nr 12.

Horyzontalny wymiar praw konstytucyjnych, red. M. Florczak-Wątor, Wydawnictwo Uniwersytetu Jagiellońskiego, Kraków 2014.

Jarass H., [w:] H. Jarass, B. Pieroth, Grundgesetz für die Bundesrepublik Deutschland. Kommentar, 7. Auflage, C.H. Beck, München 2004.

${ }^{32}$ Najczęściej przywoływane jest tu stanowisko J. Schwabego zaprezentowane [w:] Die sogenannte Drittwirkung der Grundrechte. Zur Einwirkung der Grundrechte auf den Privatrechtsverkehr, München 1971, s. 157 oraz „Drittwirkung“ und kein Ende, „Neue Juristische Wochenschrift” 1973, nr 26, s. 229 i n.

${ }_{33}$ Confer np. J. Eschenbach, F. Nienbaum, Von der mittelbaren Drittwirkung unmittelbar zur staatlichen Bevormundung, „Neue Zeitschrift für Verwaltungsrecht” 1994, s. 1079-1082; H. Sendler, Unmittelbare Drittwirkung der Grundrechte durch die Hintertür, „Neue Juristische Wochenschrift” 1994, s. 709-710. 
Kunig Ph., [w:] I. von Münch, Ph. Kunig, Grundgesetz-Kommentar, Band 1, 5. Aufl. 2000.

Linders H., Über die Frage der unmittelbaren Bedeutung der Grundrechtsbestimmungen des Bonner Grundgesetzes für den privatrechtlichen Rechtsverkehr. Ein Beitrag zum Problem der ,Drittwirkung “ der Grundrechtsbestimmungen, Bielefeld 1961, maszynopis.

Münch von I., [w:] I. von Münch, Ph. Kunig, Grundgesetz-Kommentar, Band 1, 5. Aufl. 2000.

Nipperdey H.C., [w:] K.A. Bettermann, H.C. Nipperdey, U. Scheuner, Die Grundrechte, Band IV/2, 1962.

Park K.H., Die Drittwirkung der Grundrechte des Grundgesetzes im Vergleich zum koreanischen Verfassungsrecht, Halle (Saale) 2004.

Preuss U., The German Drittwirkung Doctirne and Its Socio-Political Background, [w:] The Constitution in Private Relation: Expanding Constitutionalism, eds A. Sajo, R. Uitz, Utrecht, Eleven International Publishing 2005.

Radziewicz P., Pojęcie horyzontalnego skutku norm konstytucyjnych - uwagi wprowadzajace z perspektywy prawa konstytucyjnego, [w:] Horyzontalne oddziaływanie Konstytucji Rzeczypospolitej Polskiej oraz Konwencji o Ochronie Praw Człowieka i Podstawowych. Wolności, red. A. Młynarska-Sobaczewska, P. Radziewcz, Studia i Materiały Trybunału Konstytucyjnego Tom LVI, Warszawa 2015.

Ruffert M., Vorrang der Verfassung und Eigenständigkeit des Privatrechts. Eine verfassungsrechtliche Untersuchung zur Privatrechtswirkung des Grundgesetzes, Tübingen 2001.

Schwabe J., Die sogenannte Drittwirkung der Grundrechte. Zur Einwirkung der Grundrechte auf den Privatrechtsverkehr, München 1971

Schwabe J., ,, Drittwirkung “ und kein Ende, „Neue Juristische Wochenschrift” 1973, nr 26.

Sendler H., Unmittelbare Drittwirkung der Grundrechte durch die Hintertür, „Neue Juristische Wochenschrift" 1994.

Skwara B., W obronie bezpośredniego horyzontalnego obowiazywania praw człowieka, „Przegląd Sejmowy" 2017, nr 1.

Starck Ch., Die Grundrechte des Grundgesetzes - zugleich ein Beitrag zu den Grenzen der Verfassungsauslegung, „Juristische Schulung” 1981.

Wróblewska I., Poziome działanie praw jednostki jako rozwiazanie ustrojowe, „Przegląd Prawa Konstytucyjnego" 2014, nr 1.

Wróblewska I., Horyzontalne działanie praw podstawowych w Niemczech, [w:] Oddziaływanie wspótczesnych konstytucji na stosunki między podmiotami prywatnymi, red. naukowy M. Florczak-Wątor, Wydawnictwo Księgarnia Akademicka, Kraków 2015.

Wróblewska I., Glosa do wyroku Federalnego Sqdu Konstytucyjnego z dnia 22 lutego 2011 r., 1 BvR 699/06, BVerfGE 128,226 - Fraport, „Przegląd Prawa Konstytucyjnego” 2017 , nr 5 . 